J. Clin. Chem. Clin. Biochem.

Vol. 19,1981 , pp. 159-164

\title{
Plasma Polyamine Levels in Patients with Liver Insufficiency
}

\author{
By H. Desser
}

Ludwig Boltzmann Institut für Leukämieforschung \& Hämatologie, (Prof. Dr. A. Stacher), Vienna, Austria

\section{G. Kleinberger}

I. Medizinische Universitätsklinik, (Prof. Dr. Dr. h.c. E. Deutsch), Vienna, Austria, and

\section{J. Kläring}

EDV-Zentrum, Veterinärmedizinische Universität, (Prof. Dr. G. Keck), Vienna, Austria

(Received June 6,1980/October 8, 1980)

Summary: Plasma polyamines (spermidine and spermine) and diamines (diaminopropane, putrescine, and cadaverine) were determined after cold acid extraction of the blood plasma of patients suffering from severe liver insufficiency. Correlations were made with liver function tests, i.e. cholinesterase activity and normotest, a global test for the ability of the liver to synthesize the blood clotting factors II, VII and X. The plasma polyamine levels of patients were compared with those of a normal population.

Relevant statistical approaches demonstrated a normal distribution of the values for the healthy control group and an abnormal distribution in the diseased group. Within both groups the polyamines were found to be mutually linearly correlated with the exception of the putrescine - spermine pair in the normals and the diaminopropane/spermine pair in the patients.

A comparison between the diseased and healthy groups demonstrated significant elevations of putrescine, cadaverine, and spermidine in the former. In $78 \%$ of the patients, at least one of the polyamines was found to be abnormally elevated, whereas no elevations whatsoever were observed in $22 \%$ of the cases. Putrescine, at concentrations up to $3 \mu \mathrm{mol} / 1$, and cadaverine up to $6 \mu \mathrm{mol} / 1$ showed the highest elevations in comparison to normals $(85.3 \pm 35.3 \mathrm{nmol} / 1$ for putrescine and lower than $20 \mathrm{nmol} / 1$ for cadaverine). Spermidine, spermine and diaminopropane concentrations reached concentrations of approximately $1 \mu \mathrm{mol} / 1,500 \mathrm{nmol} / \mathrm{l}$ and $150 \mathrm{nmol} / \mathrm{l}$, compared with the mean normal values of $94.6 \pm 34.5$ $\mathrm{nmol} / 1,39.8 \pm 29.2 \mathrm{nmol} / \mathrm{l}$, and $16.9 \pm 9.31 \mathrm{nmol} / \mathrm{l}$, respectively. In patients, cadaverine is inversely correlated with the liver normotest, and spermine is directly correlated with cholinesterase activity. Liver involvement is discussed with regard to the value of polyamine levels as tumour markers. No definite conclusions can be drawn as to the cause of the polyamine elevations found in liver-diseased patients.

\section{Der Polyamingehalt des Blutplasmas von Patienten mit Leberschaden}

Zusammenfassung: Der Gehalt der Polyamine Spermidin und Spermin sowie der Diamine Diaminopropan, Putrescin und Cadaverin wurde nach Extraktion mit kalter Säure im Blutplasma von Patienten mit schwerer Leberinsuffizienz bestimmt. Zusammenhänge mit Ergebnissen von Leberfunktionsprüfungen wurden hergestellt, nämlich mit Cholinesteraseaktivität und dem Normotest, einem umfassenden Test für die Fähigkeit der Leber, die Gerinnungsfaktoren II, VII und X zu bilden. Die Patienten wurden außerdem hinsichtlich ihres Polyamingehaltes mit einer gesunden Population verglichen.

Das statistische Verfahren zeigte eine normale Verteilung für die Werte der gesunden Kontrollgruppe und eine abnormale Verteilung in der erkrankten Gruppe. Gefunden wurde, daß innerhalb beider Gruppen die Polyamine miteinander korrelieren mit Ausnahme des Putrescin/Sperminpaares in der Kontrollgruppe und des Diaminopropan/Sperminpaares bei den Patienten. Vergleiche zwischen der erkrankten und der gesunden Gruppe zeigten signifikante Erhöhungen von Putrescin, Cadaverin und Spermin in der ersteren. Bei. $78 \%$ der Patienten war mindestens bei einem Polyamin die 
Konzentration abweichend, während in $22 \%$ der Fälle überhaupt keine Erhöhung beobachtet wurde; indem sie Putrescin-Konzentrationen bis zu $3 \mu \mathrm{mol} / \mathrm{l}$ and Cadaverin bis zu $6 \mu \mathrm{mol} / \mathrm{l}$ erreichen, zeigen sie die größte Erhöhung im Vergleich zur Normalgruppe $(85,3 \pm 35,3 \mathrm{nmol} / 1$ für Putrescin, beziehungsweise weniger als $20 \mathrm{nmol} / \mathrm{l}$ für Cadaverin). Die Konzentrationen von Spermidin, Spermin und Diaminopropan erreichen annähernd Werte von $1 \mu \mathrm{mol} / 1,500$ $\mathrm{nmol} / \mathrm{l}$ und $150 \mathrm{nmol} / \mathrm{lim}$ Vergleich zu den Mittelwerten der Normalgruppe von 94,6 $\pm 34,5 \mathrm{nmol} / 1,39,8 \pm 29,2$ $\mathrm{nmol} / 1$, beziehungsweise $16,9 \pm 9,31 \mathrm{nmol} / \mathrm{l}$. Es wird gezeigt, daß Cadaverin bei den Patienten indirekt korreliert mit den Leber-Normotestwerten und Spermin direkt korreliert mit der Cholinesteraseaktivität. Die Leberbeurteilung wurde in Bezug auf den Wert der Polyamingehalte als Tumormarker diskutiert. Keine endgültigen Schlüsse können über die Ursache der Erhöhungen der Polyamine in der Leber der Patienten gezogen werden.

\section{Introduction}

Biogenic amines are formed by decarboxylation of amino acids. Some are biologically very active, playing important roles as neurotransmitters ( $\gamma$-aminobutyric acid, dopamine, serotonine), or as hormone precursors (adrenaline, thyroxine, melatonin), or as components of coenzymes (propanolamine, cysteamine, $\beta$-alanine) (1). During recent years, increased interest has been shown in aliphatic biogenic amines, designated polyamines. They include putrescine, spermidine, and spermine, which originate from their amino acid precursors ornithine and methionine. Also of biological importance are their homologues, cadaverine (most likely originating from lysine) and diaminopropane (2-7).

It is known that polyamines are found in all living cells and are deaminated by a heterogeneous group of polyand di-amino-oxidases (8-13). Furthermore, their degradation by oxidation following acetylation, has been shown to occur in brain and liver in vivo (14-16). Rosenblum \& Russel (17) directed attention to the importance of covalent bonding of the polyamines to macromolecular structures.

Our primary interest in this study is based on the observation that biosynthesis of polyamines increases in rapidly proliferating cells $(2-10,12-13)$. Polyamine determinations in biopsy material, as well as in body fluids has been suggested as a monitor for the progress of tumour patients $(5,8,18-20)$. The specificity of the polyamines as tumour markers was shown, however, to be limited, because their concentrations vary under physiological conditions. Polyamine concentrations are, for instance, influenced by age, sex, diet and pregnancy (18). Some non-malignant . diseases affect polyamine serum and urine concentrations to an even higher degree, i.e. uraemia, atherosclerosis, polycythaemia vera, cystic fibrosis, psoriasis, infections etc. (reviewed in 1.c. 5, 8, 18). Little is known about the influence of liver diseases on polyamine metabolism. A few investigators have observed that some patients with hepatitis, cirrhosis of the liver, and liver abscesses have high polyamine concentrations in serum or urine (21-26). To our knowledge, systematic investigations have not been carried out. In experimental animals, it has been shown that changes in liver function and regeneration (toxin action, hepatectomies, chemically induced carcinogenesis) leads to changes in polyamine concentration in this organ $(8,18,27-35)$. Therefore, with changes in liver function, a change in polyamine concentrations in serum and/or urine can be expected.

In the following investigation, the concentration of polyamines in the blood of patients with liver diseases was correlated with the severity of the disturbed liver function, as defined by the normotest and by plasma cholinester ase activities.

\section{Materials and Methods}

The study included 64 untreated patients with severe liver diseases (61\% men, $39 \%$ women), aged 10 to 73 years with normotest values below $50 \%$ (normal range: $70-100 \%$ ) and/or with cholinesterase activity under $1.0 \mathrm{kU} / 1$ (normal range: $2.5-3.5 \mathrm{kU} / 1$ ). Liver insufficiency was due to acute liver failure (17 patients), cirrhosis with hepatic coma (18 patients), cirrhosis with hepatic coma (18 patients), cirrhosis without hepatic coma (17 patients), and a mixed population consisting of patients with hepatitis, shock liver or sepsis (12 patients). Patients with malignancies were excluded from this study. The blood plasma of 20 healthy volunteers aged 26 to 39 , average age of $32.8 \pm 4.8$ years, of which $70 \%$ were males and $30 \%$ females, were utilized as controls. The study was conducted with approval of the Ethics and Research Committees of the General Hospital of Vienna.

\section{Sample preparation \\ Immediately after admission, blood samples were taken at room temperature from liver diseased patients into heparinized tubes, and the plasma was frozen at $-20^{\circ} \mathrm{C}$ until further handling. \\ In preparation for analysis of polyamines, $33 \mathrm{~g} / 1 \mathrm{5}$-sulfosalicylic acid in $0.1 \mathrm{~mol} / 1 \mathrm{HCl}$ was added to deproteinize the plasma and left to stand for $30 \mathrm{~min}$ at $0^{\circ} \mathrm{C}$. The resulting suspension was centrifuged at $3000 \mathrm{~g}$ for $10 \mathrm{~min}$. The precipitate was washed twice with $3 \mathrm{~g} / 1 \mathrm{5}$-sulfosalicylic acid in $0.1 \mathrm{~mol} / 1 \mathrm{HCl}$. The supernatants were collected and freeze dried. The residues were dissolved in $1.5 \mathrm{ml} 0.1 \mathrm{~mol} / 1 \mathrm{HCl}$ and centrifuged for $2.5 \mathrm{~min}$ at $15000 \mathrm{~g}$. Samples of $300 \mu \mathrm{l}$ were applied to the chromatograph for separation.}

\section{Analytical procedure}

For separation of polyamines, a strongly acidic cation'exchange resin was employed. A fluorescence detector was used for 
measurement of the primary diamines after reaction with 0 -phthalaldehyde. The procedure has been described in detail elsewhere (36). Identity of the diaminopropane peak has not yet been determined with certainty. Cochromatograms of physiological samples with a diaminopropane test solution, however, indicated good agreement of retention times and congruence of peaks. Normotest, which measures blood clotting factors II, VII and X as protrombin time (37-38), and cholinesterase activity obtained through the established butyrylthiocholine method (39) show good correlation with liver dysfunction (37-38).

\section{Statistics}

Data were submitted to the following statistical tests at the computer center of the University of Veterinary Medicine:

1. Test for normal distribution applying the Kolomogorov Smirnov method (40).

2. Calculation of correlation between variables within the disease group and within the healthy population according to Kendall (40).

3. Comparison between patients and the normal population by means of the U-paired rank classification test after MannWhitney-Wilcoxon (40).

Individual values are defined as increased if they exceed the mean value of the control group by more than 2 times standard deviation.

\section{Results}

In table 1 the mean values of polyamines in the normal population are shown. Statistical evaluation of the data of this group revealed the existence of a normal distribution for the variables.

Within the normal and within the diseased group, resulting correlations are displayed in table 2 . In the normal group all polyamine pairs were found to be correlated, with the exception of the putrescine/spermine pair. In patients, all pairs, with exception of the diamino-
Tab. 1. Polyamine content of plasma from normal subjects in $\mathrm{nmol} / \mathrm{l}$.

\begin{tabular}{lcclll}
\hline & $\bar{x}$ & $s$ & $(n)$ & $\begin{array}{l}\text { Mini- } \\
\text { mum }\end{array}$ & $\begin{array}{l}\text { Maxi- } \\
\text { mum }\end{array}$ \\
\hline $\begin{array}{l}\text { Diamino- } \\
\text { propane }\end{array}$ & $16.85 \pm 9.31$ & $(20)$ & $\phi$ & 35.00 \\
Putrescine & $85.25 \pm 35.33$ & $(20)$ & 47.00 & 178.00 \\
Cadaverine & $0 \quad[<20]$ & $(20)$ & $\phi$ & $\phi$ \\
Spermidine & $94.60 \pm 34.50$ & $(20)$ & 48.00 & 158.00 \\
Spermine & $39.80 \pm 29.24$ & (20) $\phi$ & 110.00 \\
\hline
\end{tabular}

$\bar{x} \pm s(n)=$ mean \pm standard deviation (number of cases) $\phi=$ not detectable

propane/spermine pair, were found to be correlated. Furthermore, cadaverine which, in contrast to normals, was frequently found in patients, was also found to be correlated with the other polyamines. Cadaverine was also found to be inversely correlated to values of the liver normotest, whereas spermine was calculated to be dependent on cholinesterase activity.

The comparison between the normal and diseased group is shown in table 3 . This comparison had to be calculated

Tab. 3. Comparison of polyamine content in the plasma of healthy and diseased subjects. Rank average value*.

\begin{tabular}{llll}
\hline & Normals & Patients & $P$ \\
\hline Diaminopropane & $39.4(20)$ & $37.5(55)$ & n.s. \\
Putrescine & $21.5(20)$ & $49.1(64)$ & $<0.001$ \\
Cadaverine & $28.0(20)$ & $47.0(64)$ & $<0.001$ \\
Spermidine & $26.6(20)$ & $46.9(63)$ & $<0.01$ \\
Spermine & $43.2(20)$ & $39.5(60)$ & n.s. \\
\hline
\end{tabular}

n. s.: not significant

* U-Test according to Wilcoxon (number of cases)

Tab. 2. Dependence of the variables among each other in the normal group and in the disease group.

\begin{tabular}{|c|c|c|c|c|c|c|c|}
\hline & $\begin{array}{l}\text { Diamino- } \\
\text { propane }\end{array}$ & Putrescine & Cadaverine & Spermidine & Spermine & $\begin{array}{l}\text { Cholin- } \\
\text { esterase }\end{array}$ & Normotest \\
\hline \multicolumn{8}{|c|}{ Diseased } \\
\hline Diaminopropane & & $\begin{array}{c}\S 0.2928^{*} \\
(55)\end{array}$ & $\begin{array}{l}0.2147 * \\
(55)\end{array}$ & $\begin{array}{l}0.2706 * \\
(54)\end{array}$ & $\begin{array}{l}0.0647 \\
(51)\end{array}$ & $\begin{array}{c}-0.1138 \\
(51)\end{array}$ & $\begin{array}{l}-0.0484 \\
(54)\end{array}$ \\
\hline Putrescine & $\begin{array}{l}0.3360 * \\
(20)\end{array}$ & & $\begin{array}{l}0.4209^{*} \\
(64)\end{array}$ & $\begin{array}{l}0.4112^{*} \\
(63)\end{array}$ & $\begin{array}{l}0.2629 * \\
(60)\end{array}$ & $\begin{array}{l}0.0823 \\
(60)\end{array}$ & $\begin{array}{c}-0.0323 \\
(63)\end{array}$ \\
\hline Cadaverine & & & & $\begin{array}{l}0.3341^{*} \\
(63)\end{array}$ & $\begin{array}{l}0.2886^{*} \\
(60)\end{array}$ & $\begin{array}{l}0.0765 \\
(60)\end{array}$ & $\begin{array}{c}-0.1788^{*} \\
(63)\end{array}$ \\
\hline Spermidine & $\begin{array}{l}0.3617 * \\
(20)\end{array}$ & $\begin{array}{l}0.4085^{*} \\
(20)\end{array}$ & & & $\begin{array}{l}0.1884^{*} \\
(59)\end{array}$ & $\begin{array}{l}0.1088 \\
(59)\end{array}$ & $\begin{array}{c}-0.1583 \\
(62)\end{array}$ \\
\hline Spermine & $\begin{array}{l}0.4216^{*} \\
(20)\end{array}$ & $\begin{array}{l}0.2426 \\
(20)\end{array}$ & & $\begin{array}{l}0.3764^{*} \\
(20)\end{array}$ & & $\begin{array}{l}0.2256^{*} \\
(57)\end{array}$ & $\begin{array}{c}-0.1192 \\
(59)\end{array}$ \\
\hline Cholinesterase & & & & & & & $\begin{array}{l}0.0278 \\
(60)\end{array}$ \\
\hline
\end{tabular}

§: Correlation coefficient (number of data pairs).

*: significant correlation $\mathrm{p}<0.05$. 
by the Mann-Whitney-U-Wilcoxon rank classification test, since data obtained in the diseased group were found to be abnormally distributed. Significant differences between diseased and healthy populations were observed in plasma polyamine concentrations for putrescine $(\mathrm{p}<0.001)$, cadaverine $(p<0.001)$, and spermidine $(p<0.01)$. In contrast, diaminopropane and spermine concentrations in both groups were not distinguishable.

In 51 out of 64 patients, we were able to obtain the complete profile of all 5 polyamines in each patient. The distribution frequency of elevated values vs. norm were found to be as follows: In $22 \%$ of patients, no polyamines were found to be elevated. All 5 polyamines were elevated in about $4 \%$ of the cases, 4 in 10\%, 3 in 14\%, 2 in 39\%, and 1 in $22 \%$, respectively.

Regarding the incidence of elevations of individual polyamines, $14 \%$ of all patients had elevated diaminopropane concentrations, $59 \%$ elevated putrescine concentrations, $43 \%$ elevated spermidine concentrations, $10 \%$ elevated spermine concentrations, and $37 \%$ elevated cadaverine concentrations in their plasma.

The scattergram (fig. 1) demonstrates extent and relative distribution of amine levels in plasma of diseased and healthy persons. Especially putrescine and cadaverine exhibit extremely high values in some patients, reaching 30 times the norm for putrescine and 300 times the norm for cadaverine, corresponding to a putrescine concentration of approximately $3 \mu \mathrm{mol} / \mathrm{l}$ and a cadaverine concentration of approximately $6 \mu \mathrm{mol} / \mathrm{l}$. Spermidine and spermine occasionally reached levels 10 times higher than normal; diaminopropane was found in one case to be 8 times above normal, but in all other cases they did not exceed 5 times the norm.

\section{Discussion}

The normal distribution for polyamine values in the control group (Kolmogorov-Smirnov test) is an indication for a homogenous population. On the other hand, polyamine values of the diseased group show an abnormal distribution.

In general, it has been established that the concentration of the polyamines in the blood plasma of liverdiseased persons is frequently elevated compared to the concentration found in healthy persons. Particularly putrescine and cadaverine concentrations are increased to such an extent (scattergram, fig. 1) that they considerably exceed the values found in other pathological conditions $(5,8,18)$. As can be seen, spermidine concentrations are also frequently found to be elevated, the extent of increase also being of importance. Although the mean spermine value of the diseased group (tab. 3) is not significantly different from the mean of the normal

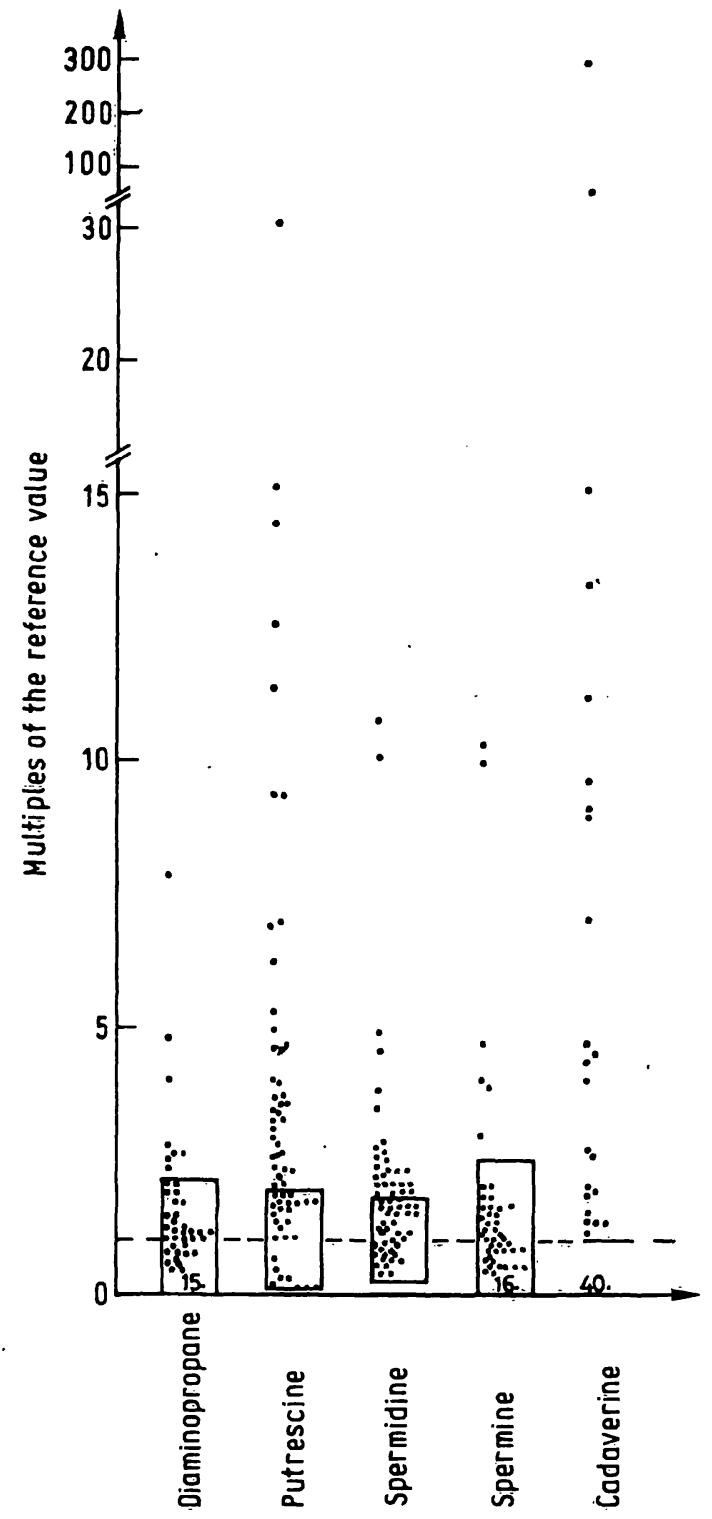

Fig. 1. Scattergram, showing increase in polyamine values compared to the reference range.

Average of the reference set $=1$.

Sensitivity limit for cadaverine $=20 \mathrm{nmol} / \mathrm{l}$.

Number of values below the sensitivity level as number on the abscissa.

Values framed show the reference range $(\bar{x} \pm 2 s)$.

group, cases were occasionally observed with highly elevated levels for this polyamine too. Diaminopropane values are less noteworthy.

In addition, inverse correlation of the cadaverine concentration with the values of normotest is of special interest, as this test corresponds to the extent of disturb. ance in liver function (37-38). The empirically deduced formula for the relationship in this case is: cadaverine $=$ $-5.9 \times$ normotest +380 ( 63 data pairs). This means that cadaverine will probably be detected in plasma of patients whose normotest value is found to be below $64 \%$; alternatively expressed, with normotest values below $10 \%$, cadaverine will be expected to attain concentrations higher than $300 \mathrm{nmol} / 1$. 
Although for putrescine, spermidine and spermine no significant dependence on normotest was calculable, a remarkable tendency towards an inverse relationship is observed.

The statistically recognized correlation between spermine content and cholinesterase activity is a further indication for relevance of polyamine levels in liver-diseased persons, since it is known that cholinesterase activity is indicative of the degree of liver malfunction in patients with liver disease.

Regarding the variability in polyamine values (scattergram, fig. 1) it seems unlikely however that polyamine assays can be reliable indicators of liver dysfunction. Differentiation of the patient population into diagnostically defined subgroups of liver insufficiences and recomparison of the quoted variables will certainly reveal a finer picture. An expanded study involving more patients would have to be undertaken to achieve this.

The frequency with which increases in a particular polyamine value occurred did not exceed $60 \%$, e.g. for putrescine. In 51 patients, for whom all variables were accessible, a hypernormal value of at least one investigated polyamine was exhibited with a frequency of $78 \%$. Only $22 \%$ of patients showed no increase in any polyamine level whatsoever.

Regarding the discussed possibility of using polyamine profiles as a tumour marker $(5,8,10,18)$, it is important to take into consideration that, with eventual liver involvement, changes in obtained polyamine values can be expected. This restricts the specificity of polyamine determinations for tumour diagnosis. Therefore, in evaluating polyamine levels in patients with malignant diseases, this fact must be taken into account. Nevertheless, the observation of changes in polyamine levels in individual patients is a valuable supplement to clinical evaluation of the patient's progress and the success of therapy $(8,18)$.

Within our normal group, a correlation between all the specified polyamines was observed with the exception of the putrescine/spermine pair, where no linear mathematical dependence in blood plasma could be found. On the other hand, in patient's plasma, all paired polyamine values were found to be correlated with exception of the diaminopropane/spermine pair.

Our data demonstrate that the concentrations of the polyamines in patients with liver disease are subject to great changes in comparison to normal controls. In contrast, the quotient of paired polyamine concentrations among sick and among healthy people are in general not significantly distinguishable. From the data obtained, it can therefore not be concluded that polyamine metabolism in liver-diseased persons is pathologically disturbed.

In this investigation, the polyamine content was determined after cold acid extraction. This method frees polyamines that are not covalently bound, either to macromolecules, or in the form of low molecular weight derivatives, e.g. acetylated amines. The liver is most likely a privileged site for polyamine metabolism (8-11, 41). Since acetylation is an important step in polyamine catabolism (14-15) it might be possible to show that a change in the relationship between acetylated and non-acetylated polyamines occurs in our liverdiseased patients, with the reservation that with further catabolism of the acetylated polyamines, the pattem would be changed again. To date, it has not been possible for us to test this hypothesis by determinations of covalently and non-covalently bound polyamines directly. An analytical procedure to this end is at present being developed. On the other hand, it is possible to examine polyamine concentrations before and after hot acid hydrolysis in order to obtain an idea of extent of covalent bonding present. Furthermore, it would be of value to investigate enzyme activities involved in polyamine catabolism in experimental animals with established liver damage.

Using cold acid extraction, we have shown that diaminopropane, cadaverine, putrescine, spermidine, and spermine are frequently elevated in the plasma of patients with severe liver damage as compared to normal persons. It has not been determined whether these pathological increases are a result of release of existing endogenous polyamines from disturbed liver cells or from an accumulation of metabolites as a result of blockade of catabolism of inherant or exogenous material. It can be assumed that both mechanisms occur concurrently. This could be tested in experimental animals and with a mathematical model. In humans, it would be of value to compare the extent of the pathological polyamine aberration along with a detailed differential diagnostic description of patients.

\section{Acknowledgments}

This work was financially supported by the National Bank of Austria (Jubiläumsfondsprojekt 1057). I am grateful to Miss Eva Malek and Mrs. Renate Salloum for their excellent technical assistance. 


\section{References}

1. Guggenheim, M. (ed.) (1951), Die Biogenen Amine, 4th ed. S. Karger, Basel.

2. Cohen, S. S. (ed.) (1971), Introduction to the Polyamines, Prentice Hall, Inc, New-Jersey.

3. Bachrach, U. (ed.) (1973), Function of Naturally Occurring Polyamines, Academic Press, New York.

4. Campbell, R. A., Morris, D. R., Bartos, D., Daves, G. D. \& Bartos, F. (eds.) (1978), Advances in Polyamine Research, Vol. 1. Raven Press, New York.

5. Campbell, R. A., Morris, D. R., Bartos, D., Daves, G. D. \& Bartos, F. (eds.) (1978), Advances in Polyamine Research, Vol. 2. Raven Press, New York.

6. Morris, D. R. (1978), Biosynthesis of Polyamines. In: Advances in Polyamine Research, Vol. 1. (Campbell, R. A., Morris, D. R., Bartos, D., Daves, G. D. \& Bartos, F. eds.) Raven Press, New York, pp. 13-15.

7. Gaugas, J. M. (ed.) (1980), Polyamines in Biomedical Research, John Wiley, Chichester, England.

8. Jänne, J., Pösö, H. \& Raina, A. (1978), Biochim. Biophys. Acta 473, 241-293.

9. Hölltä, E. (1977), Biochemistry 16, 91-100.

10. Williams-Ashman, H. G. \& Canellakis, Z. N. (1979), Perspectives Biol. Med. 22, 421-453.

11. Kapellar-Adler, R. (ed.) (1970), Amine Oxidases and Methods for their Study, Wiley Interscience, New York.

12. Raina, A. \& Jänne, J. (1975), Med. Biol. 53, 121-147.

13. Maudsley, D. V. (1979), Biochem. Pharmacol. 28, 153-161.

14. Blankenship, J. \& Walle, T. (1978), In vitro studies of enzymatic synthesis and metabolism of $\mathrm{N}$-acetylated polyamines. In: Advances in Polyamine Research, (Campbell, R. A., Morris, D. R., Bartos, D., Daves, G. D. \& Bartos, F. eds.) Raven Press, New York, Vol. 2, pp. 97-110.

15. Seiler, N. \& Al-Therib, M. J. (1974), Biochem. J. 144, 29-35.

16. Blankenship, J. (1979), Proc. West. Pharmacol. Soc. 22, $115-118$.

17. Rosenblum, M. G. \& Russell, D. H. (1977), Cancer Res. 37, 47-51.

18. Russell, D. H. \& Durie, B. G. M. (eds.) (1978), Polyamines as biochemical markers of normal and malignant growth. Progr. Cancer Res. \& Therapy, Vol. 8, Raven Press, New York.

19. Bachrach, U. (1976), Ital. J. Biochem. 25, 77-93.

20. Seidenfeld, J. \& Marton, L. J. (1979), J. Natl. Cancer Inst. $63,919-931$.
21. Schimpff, S. S., Levy, C. C., Hawk, I. A. \& Russell, D. H. (1973); Polyamines - Potential roles in the diagnosis, prognosis and therapy of patients with cancer. In: Polyamines in Normal and Neoplastic Growth (Russell, D. H. ed.), Raven Press, New York, pp. 395-403.

22. Russell, D. H., Levy, C. C., Schimpff, S. C. \& Hawk, I. A. (1971), Cancer Res. 31, 1555-1558.

23. Lipton, A., Sheehan, L. M. \& Kessler jr., G. F. (1975), Cancer 35, 464-468.

24. Waalkes, T. P., Gehrke, C. W., Tormey, D. C., Zumwalt, R. W., Hueser, J. N., Kuo, K. C., Lakings, D. B.; Ahmann, D. C. \& Moertel, C. G. (1975), Cancer Therapy Rep. 59, $1103-1116$.

25. Dreyfuss, F., Chayen, R., Dreyfuss, G. Dvir, R. \& Ratan, J. (1975), Israel J. Med. Sci. 11, 785-795.

26. Durie, B. G. M., Salmon, S. E. \& Russell, D. H. (1977), Cancer Res. 37, 214-221.

27. Rozovski, S. J., Rosso, P. \& Winick, M. (1978), J. Nutr. $108,1680-1690$.

28. Antony, P. \& Schimassek, H. (1978), Cytobiol. 18, 244-253.

29. Ono, M., Inone, H. \& Takeda, Y. (1973), Biochim. Biophys. Acta 304, 495-5.04.

30. Marton, L. J. \& Heby, O. (1974), Int. J. Cancer 13, 619-628.

31. Daikuhara, Y., Tamada, F., Takigawa, M., Takeda, Y. \& Mori, Y. (1979), Gastroenterology 77, 123-132.

32. Domschke, S. \& Söling, H. D. (1973), Horm. Metab. Res. 5, 97-101.

33. Macanulty, P. A. \& Williams, J. P. G. (1977), Biochem. J. $162,109-121$

34. Furuta, H. (1978), Jap. J. Pharmacol. 28, 919-921.

35. Berdinskikh, N. K., Lyalu shko, N. M., Vasnetsova, S. S. \& Hutnyk, H. S. (1979), Ukr. Biokhim. J. 51, 541-543.

36. Desser, H., Niebauer, G. W. \& Gebhart, W. (1980), Z̈bl. Vet. Med. A, 27, 45-53.

37. Lechner, K., Niessner, H. \& Thaler, E. (1977), Seminars Thrombos. Hemostas. 4, 40-56.

38. Kleinberger, G., Thaler, E., Gassner, A. \& Lenz, A. (1979), Intensivmed. 16, 146-152.

39. Gal, J. \& Roth, E. (1957), Clin. Chim. Acta 2, 316-320.

40. Nie, N. H., Hull, C. H., Jenkins, J. G., Steinbrenner, K. \& Bent, D. H. (eds.) (1976), SPSS - Statistical Package for the Social Sciences. MacGraw Hill, New York.

41. Chapman, S. K. (1976), Drug Metabol. \& Disposition 4, 417-422.
Dr. Hans Desser

Ludwig Boltzmann Institut für Leukämieforschung und Hämatologie Hanusch Krankenhaus H. Collinstraße 30

A-1140 Vienna, Austria 